\title{
Professor Jim Rhodes
}

Jim Rhodes has championed research in the area of Thin Walled Structures (TWS) for almost 40 years. His contribution to the understanding of the behaviour of TWS is second to none and he has consequently enjoyed a high international standing in the field. He was educated at St Michael's College in Irvine and served a craft apprenticeship with Laird \& Sons Ltd, Irvine before moving to Massey Ferguson Ltd. He was awarded an HNC (with distinction) in Mechanical Engineering from Kilmarnock College, which he then followed by degree studies at the University of Strathclyde where he graduated with a first class honours BSc in Mechanical Engineering in 1966 before progressing to Doctoral study under Professor James Harvey (Head of Department and later Vice Principal of the University). He was awarded a PhD degree at Strathclyde in 1969 for research in Mechanics of Materials. His external examiner for his PhD was Professor Henry Chilver, later Lord Chilver and Vice Chancellor of Cranfield University.

With due encouragement from Professor Harvey he joined the staff of the University in 1970 and progressed through Senior Lecturer in 1977 to Reader in 1982 and then to Professor in 1991, a post he has held with distinction until his transition to Emeritus status in 2007. In recognition of his contribution to TWS the University of Strathclyde conferred on him the degree of DSc in 1991. The external examiners were, Dr Phil Bulson, Head of RARDE (Royal Armaments Research \& Development Establishment), Professor Eric Bryan, Salford University and Professor Alastair Walker, of Surrey University.

Jim's driving motivation through the years has been to elucidate all aspects of the behaviour of TWS. This research has covered a variety of topics including plates, beams, columns, shells, decking, cladding, storage racking, flooring systems and roof systems as well as crashworthiness assessment of closed and open sections for vehicles. In particular the buckling and post buckling behaviour of the structural elements has been researched in considerable detail and the "effective width" and "finite strip" approaches shown to be powerful tools in the analyst's kitbag

In a moment of supreme inspiration in 1983, he initiated the International Journal of TWS, becoming Founding Editor and Editor in Chief, a post he held until he stepped down in 1999 although he remains on the Editorial Board as Founding Editor. The Journal, published by Elsevier Applied Science, rapidly established itself as a major influence in the field. It commenced initially with 4 issues per annum but rapidly progressed and developed to the current 12 issues per year. In addition to editing this important Journal with distinction for some 15 years he has also acted as Editor (and Co-Editor) for a series of books on developments in TWS. Not only that but he has been Director (or Co-Director) of a series of International Conferences in the area of TWS, viz, Strathclyde in 1979, 1983, 1996, The Royal Society, London in 1984, Singapore in 1998 and Poland in 2001. In addition he has been a member of the Steering or Planning Committees of more than 50 Conferences held in the UK, USA, Belgium, India, Poland, Singapore, Hong Kong, and Australia. Jim was instrumental in founding the Cold Formed Steel Research Group in 1986 involving the Universities of Strathclyde, Salford and Cardiff, BRE, British Steel and with representation from the CRSA, SERC and some industrial companies at the initial meetings. This group was subsequently organised by The Steel Construction Institute. Partly through all 
this altruistic activity and partly through his own distinctive research contribution Jim Rhodes has enjoyed a high reputation in the international community, witnessed by a constant stream of invitations to lecture from across the world and a corresponding inward stream of international visitors. Departmental colleagues travelling overseas have been impressed by the number of times they have been asked to convey best wishes back to Professor Rhodes. He is as well known in USA, Australia, Japan, Singapore and Hong Kong as he is in the UK.

His research work is both theoretical and applied. While developing theoretical methods such as the finite strip, he has also been known to build and test full scale roof structures, which totally filled the department's largest laboratory! He has also worked as a consultant for many different industrial companies, carrying out both test work and theoretical work in aid of design; much of that work remains confidential to the companies. While most of his consultancy work has been related to lightweight building structures the projects he has undertaken encompass analysis and testing of microcomputer keyboards, car components and assemblies, and elements of nuclear power plants.

He has held a number of SERC \& EPSRC research contracts and undertook the UK contribution on three European Joint Research Programmes on "Connections in TWS”, “Storage Racking” and “Design rules for Cold Formed Steel Members”.

One of Professor Rhodes' great strengths has been his ability to build excellent relationships with his students. He is quite unique in this respect and it is difficult to overstate this aspect of his work. Over the years c25 Doctoral and c20 Masters students have successfully benefited from his gentle perceptive supervision. Many of these students hailed from Singapore and Hong Kong and it speaks volumes to record that for 20 years or so his students always arranged a party for him on his birthday. Many of these students are now in senior positions in Universities around the world. Equally he has been in demand as an External Examiner elsewhere and has acted as such on more than 40 occasions across the UK but also overseas. In addition he has delivered Lectures and Seminars in many Universities worldwide especially in North America and the Far East. He has also been Technical Adviser to the Cold Rolled Sections Association during the period 1970-90 and has undertaken various projects on behalf of this organisation to assist in promoting the use and development of cold formed steel sections.

Professor Rhodes has sought to disseminate the applications of his research not only in conventional ways but also through short courses for both academics and industrialists. Between 1977 and 1991 he conducted over 20 such short courses, mainly in the UK but also in India, Germany and Poland. In addition he has participated in producing various series of lecture notes on Cold Formed Steel Design, on behalf of the Cold Rolled Sections Association, for distribution to selected Civil Engineering Departments throughout the UK.

Throughout his professional career Jim has been heavily involved with Codes and Standards. For example, he was the consultant drafter and leader of the drafting team, for Part 5: (Code of Practice for design of cold formed sections) to BS 5950: (British Standard for the Structural Use of Steelwork in Building), which was published in 1987. 
He was also a Member of ECCS Committee TC 7, responsible for the initial versions of Eurocode 3 Annex A, dealing with the design of cold formed steel members for use in Buildings, and of CIB Working Commission W56-Light weight constructions and has been, since 1987, the Technical Assessor for the BSI and SEMA registration schemes for Storage Equipment companies.

Three times, he carried out assessments of drafts of Annex A to Eurocode 3 for the Building Research Establishment (1989, 1990 and 1991), and subsequently carried out assessment of the completed Eurocode 3: Part 1.3 (Design rules for cold formed steel structural members) for the Department of the Environment (DOE) and BRE, 1993. Since then, he has performed calibration of EC3: Part 1.3 for BRE for setting up the relevant National Application Document in 1997 and carried out calibrations of EC3: Part 1.4 (Design of stainless steel structural members) for BRE to assist with setting up the NAD.

One of Jim's interests has been in the use of user friendly programmes for microcomputers. He has written many of these programmes, making them available, and showing how they can be useful in research and design situations. Similarly, he has enthused undergraduates encouraging them to develop their own work in this way and avoid being solely dependent on commercial software. He has used the same approach with industry, having written computer programs for various companies and organizations. A recent programme was a checking system for the design of storage racking to the FEM (Federation Europeenne de la Manutention) code, commissioned by the Storage Equipment Manufacturers Association (SEMA).

Professor Rhodes has published his work widely. He has over 180 publications in the engineering literature including 10 books or edited books. In addition he has written more than 250 technical reports and computer programmes for industrial companies. Some of his papers have been awarded prizes, notably the George Taylor (of Australia) Prize from the Royal Aeronautical Society, 1972 and the James Clayton Paper Prize from the IMechE in 1977.

The University of Strathclyde has had a collaboration agreement with the Technical University of Lodz, Poland since 1967, and Jim has been deeply involved in this for the past 27 years, forming many friendships with colleagues from that Institution. This was recognised at the 2007 Jubilee celebration in Lodz, where Jim received an Award of Appreciation, and two days earlier, when a Jubilee seminar was arranged, with delegates from a number of Polish Universities, in honour of his scientific achievements together with those of Professor M Krolak, Lodz and Professor A I Manevitch, Dniepropetrovsk, Ukraine.

Jim's wife Hilda was a tower of strength to him, supporting him in all his activity, travelling with him occasionally and providing hospitality for many postgraduate students and visitors. Sadly Hilda died in 2003.

\section{Professor John Spence, BSc ARCST MEng PhD DSc CEng FIMechE FREng FRSA FRSE November 2007}

